\title{
Serum Soluble Transferrin Receptor-Ferritin Indices in Diagnosing and Differentiating Iron Deficiency Anemia from Anemia of Chronic Disease among Patients with Chronic Kidney Disease
}

\author{
Latif A ${ }^{\mathrm{a}}$, Hoque $\mathrm{F}^{\mathrm{b}}$, Alam MR ${ }^{\mathrm{c}}$, Khanam A ${ }^{\mathrm{d}}$, Iqbal Se, Rahim MA ${ }^{\mathrm{f}}$, Billah MMg, Rahman OM ${ }^{\mathrm{h}}$, \\ Chowdhury TA ${ }^{\mathrm{i}}$
}

\begin{abstract}
Background: Anemia is common in patients with chronic kidney disease (CKD) and this is generally anemia of chronic disease (ACD), but iron deficiency anemia (IDA) is also common. Soluble transferrin receptor (sTfR) is a useful marker for IDA. Present study was undertaken to assess the utility of sTfR as a marker of IDA and to differentiate ACD from IDA in selected group of Bangladeshi patients with CKD.

Methods: This cross-sectional study was conducted in the Department of Nephrology, BSMMU, Dhaka, Bangladesh from January 2013 to December 2014. Patients with anemia admitted in Nephrology Department, whether on hemodialysis or not and Medicine Department of BSMMU were taken for study. The study population was further divided into two groups; Group A, patients (30) who were having IDA and Group B, patients (40) with ACD and a control group was also selected. Data were collected by face to face interview and laboratory investigations with a self-administered questionnaire.

Results: The mean age of the patients in Group A and Group B were $38.40 \pm 13.23$ and $34.85 \pm 10.52$ years respectively and male-female ratio were 0.5:1 and 1:0.5. Mean sTfR level was higher $(4.81 \pm 1.64 \mu \mathrm{g} / \mathrm{ml})$ in patients with IDA than $(2.89 \pm 1.40 \mu \mathrm{g} / \mathrm{ml})$ in patients with $A C D(p<0.0001)$. Mean ferritin level was $599.59 \pm 449.15 \mu \mathrm{g} / \mathrm{L}$ in $A C D$ patients whereas $101.23 \pm 119.42$ in IDA patients ( $<<0.0001)$. Total iron binding capacity (TIBC) was more in $A C D$ patients with sTfRe" $3 \mu \mathrm{g} / \mathrm{ml}$ as compared to ACD patients with $s T f R<3 \mu \mathrm{g} / \mathrm{ml}$. Transferrin saturation (TSAT) level was significantly decreased in ACD patients with sTfRe" $3 \mu \mathrm{g} / \mathrm{ml}$ as compared to ACD patients with $s T f R<3 \mu \mathrm{g} / \mathrm{ml}$. sTfR and ferritin indices between group A (IDA) and group B (ACD) shows mean sTfR:logSF level was significantly $(P<0.001)$ high in group $A(2.71 \pm 1.13)$ in comparison to group $B(1.08 \pm 0.54)$. Mean log $s T F R: S F$ was also significantly higher $(P<0.05)$ in group $A(0.001 \pm 0.0008)$ compared to group $B(0.013 \pm 0.012)$.

Conclusion: sTfR level has a comparable ability to serum ferritin in diagnosing IDA and ACD. However, sTfR and serum ferritin alone cannot definitely exclude coexisting iron deficiency in ACD. Log sTfR/ferritin index has role in identifying development of iron deficiency in $A C D$ whereas $S T f R / \log S F$ ratio can differentiate pure IDA from ACD with or without iron deficiency. Thus, it is important to estimate both serum sTfR and sTfRferritin indices to be able to differentiate pure IDA, ACD and ACD with co-existing iron deficiency thus providing a non-invasive alternative to bone marrow iron.
\end{abstract}

Key words: Anemia, anemia of chronic disease, ferritin, iron deficiency anemia, soluble transferrin receptor.

(BIRDEM Med J 2019; 9(2): 151-156)

\footnotetext{
Author Information

a. Dr. Abdul Latif, Registrar, Nephrology \& Dialysis Unit-3, BIRDEM, Dhaka.

b. Dr. Farhana Hoque, Associate Professor, Physiology, Kumudini Women's Medical College, Mirzapur, Tangail.

c. Prof.. Muhammad Rafiqul Alam, Professor, Nephrology, BSMMU, Dhaka.

d. Prof. Asia Khanam, Professor, Nephrology, BSMMU, Dhaka.

e. Prof. Sarwar Iqbal, Professor \& Head, Nephrology, BIRDEM, Dhaka.

f. Dr. Muhammad Abdur Rahim, Associate Professor, Nephrology \& Dialysis Unit-1, BIRDEM, Dhaka.

g. Dr. Md Mostarshid Billah, Assistant Professor, Nephrology \& Dialysis Unit -3, BIRDEM, Dhaka.

h. Dr. Md Obaidur Rahman, Assistant Professor, Nephrology, Cumilla Medical College, Cumilla.

i. Dr. Tufayel Ahmed Chowdhury, Registrar, Nephrology Unit-1, BIRDEM, Dhaka
}

Address of correspondence: Dr. Abdul Latif, Registrar, Nephrology \& Dialysis Unit-3, BIRDEM General Hospital, 122 Kazi Nazrul Islam Avenue, Shahbag, Dhaka-1000, Bangladesh. Email: 1tfmn7879@gmail.com

Received: November 7, 2018

Accepted: February 28, 2019 


\section{Introduction}

Chronic kidney disease (CKD) is an important chronic, non-communicable epidemic disease. Up to $80 \%$ of patients with CKD may have anaemia. ${ }^{1}$ CKD patients suffer from various types of anemia including iron deficiency anemia (IDA) and anemia of chronic disease (ACD). These are two common forms of anemia that have interrelated characteristics, causing a diagnostic predicament. ACD is characterized by hypoferremia in the presence of adequate reticulo-endothelial iron stores. Absolute or functional iron deficiency is present in 25$38 \%$ of patients with anemia of CKD. ${ }^{2}$ Serum ferritin and transferrin saturation (TSAT) are two most commonly done tests used for evaluating IDA. However, these tests do not consistently reflect the iron status of patients with CKD on hemodialysis. ${ }^{3}$ Serum ferritin and transferrin are considerably influenced by acute phase responses in inflammation. Total iron binding capacity (TIBC) is a negative acute phase reactant. Moreover, TSAT fluctuates because of diurnal variation in serum iron levels.

In recent years, soluble transferrin receptor (sTfR) has been introduced as a sensitive, early and valuable marker of iron depletion. ${ }^{4}$ sTfR is a truncated form of the transferrin receptor present on erythroblasts in bone marrow and many other cells. sTfR concentration is not affected by inflammation or infection rather in conditions where iron deficiency co-exists with ACD, STfR raises secondary to underlying iron deficiency. Moreover, sTfR levels also reflect the rate of erythropoiesis, So, its specificity decreases as a sole marker of iron deficiency. Synthesis of transferrin receptor and the iron storage protein ferritin are reciprocally linked to cellular iron content. Thus, because of this reciprocal relationship between sTfR and serum ferritin, the sTfR/ferritin ratio reflects the iron status over the entire range. The present study was undertaken to assess the role of sTfR-ferritin indices to differentiate ACD from IDA and also to diagnose coexisting IDA with ACD in CKD patients whether on or not on hemodialysis.

\section{Methods}

This cross-sectional study was conducted in the Department of Nephrology, Bangabandhu Sheikh Mujib Medical University (BSMMU), Dhaka, Bangladesh from January 2013 to December 2014. A total of 70 adult ( $>18$ years) male and non-pregnant female patients with anemia, admitted in Nephrology and Medicine Departments of BSMMU were purposively included in this study. A total of 30 age matched healthy subjects were also included as control. Selected subjects were evaluated clinically and by laboratory parameters and data were recorded in structured questionnaire. Selected patients were subjected to do following tests: complete blood count with erythrocyte sedimentation rate, red blood cell indices, reticulocyte count, and peripheral blood film (PBF), iron profile (serum total iron, ferritin, TIBC, TSAT), C-reactive protein (CRP) and sTfR. sTfR was done by particle enhanced immunoturbidimetric assay; (Roche/Hitachi analyzers, Cat. No. 12148315). Serum CRP was done by using latex agglutination test using kit CRP Latex CHEMELEX. Complete blood count was done using Sysmex KX21 autoanalyzer, serum creatinine by enzymatic method on autoanalyzer. Serum ferritin was estimated by immunoradiometric assay and serum iron by colorimetric assay at $560 \mathrm{~nm}$.

Data were analyzed by using statistical package for social science (SPSS) version 20 for Windows. Numerical data were expressed as mean \pm standard deviation and number (percentage) as appropriate. Unpaired Student's t test, Mann-Whitney 'U' test, Chi squared test (Fisher exact modification) and ANOVA ' $F$ ' test and ANOVA (Post hoc) were performed to calculate statistical difference and/or association between groups, as appropriate. A $p$-value $<0.05$ was taken as significant.

Patients were divided into 2 groups: Group A: patients with IDA ( $n=30)$ having a serum ferritin level of $<200$ $\mathrm{ng} / \mathrm{ml}$ (in patients on haemodialysis) and $<100 \mathrm{ng} / \mathrm{ml}$ in non-haemodialysis CKD subjects. ${ }^{5}$ Group B consisted of patients with $\operatorname{ACD}(n=40)$ defined as those having a chronic disease persisting for more than two months who were anaemic with a CRP of $>6 \mathrm{ng} / \mathrm{ml}$. A third group (Group C) consisting of healthy controls, were also kept in the study. Patients with hematological malignancies, hemolytic anemia, history of acute blood loss, recent blood transfusion, active infection, receiving iron supplementation within 1 month were excluded from the study. Here, expected value of sTfR was 2.2$5.0 \mu \mathrm{g} / \mathrm{ml}$ (Roche/Hitachi analyzers) in normal subjects.

\section{Results}

Total patients were 100 including 70 study subjects and 30 controls. Base-line characteristics are shown 
in Table I. Different parameters of red cell indices and reticulocyte counts are presented in Table II. Serum iron, total iron binding capacity, ferritin and transferrin saturation are presented in Table III. Soluble transferrin receptor levels of different groups are shown in Table IV. Mean sTfR higher in Group A compared to Group B and C and showed significant difference $(p=0.0001)$. However, comparison between group $\mathrm{B}$ and $\mathrm{C}$ did not show any significant difference $(\mathrm{p}=0.829)$

Table I Base-line characteristics of the study subjects

\begin{tabular}{lcccc} 
Parameter & Group A $(\mathrm{n}=30)$ & Group B $(\mathrm{n}=40)$ & Group C $(\mathrm{n}=30)$ & p value \\
& $\mathrm{N}(\%)$ & $\mathrm{N}(\%)$ & $\mathrm{N}(\%)$ & \\
\hline Mean age (years) & $38.40 \pm 13.23$ & $34.85 \pm 10.52$ & $38.00 \pm 2.08$ & 0.255 \\
& {$[18.070 .0]$} & {$[19.065 .0]$} & {$[34.041 .0]$} & \\
Sex Male & $10(33.3)$ & $26(65.0)$ & $21(70.0)$ & 0.007 \\
$\quad$ Female & $20(66.7)$ & $14(35.0)$ & $9(30.0)$ & \\
BMI $\left(\mathrm{kg} / \mathrm{m}^{2}\right)$ & $22.63 \pm 4.00$ & $20.03 \pm 3.26$ & $25.42 \pm 1.41$ & 0.0001 \\
& {$[14.9030 .42]$} & {$[14.8225 .65]$} & {$[23.4527 .72]$} & \\
\hline
\end{tabular}

Table II Red blood cell indices and reticulocyte count of the study subjects

\begin{tabular}{|c|c|c|c|c|}
\hline Parameter & $\begin{array}{c}\text { Group A } \\
(\mathrm{n}=30)\end{array}$ & $\begin{array}{c}\text { Group B } \\
(\mathrm{n}=40)\end{array}$ & $\begin{array}{c}\text { Group C } \\
(\mathrm{n}=30)\end{array}$ & $p$ value \\
\hline \multicolumn{5}{|c|}{ Haemoglobin (g/dl) } \\
\hline & $8.29 \pm 1.20$ & $7.88 \pm 1.22$ & $14.15 \pm 0.88$ & 0.0001 \\
\hline & {$\left[\begin{array}{lll}5.60 & 10.10\end{array}\right]$} & {$\left[\begin{array}{lll}5.70 & 9.80\end{array}\right]$} & {$\left[\begin{array}{ll}12.90 & 15.50\end{array}\right]$} & \\
\hline \multicolumn{5}{|c|}{$\mathbf{R B C}\left(\mathrm{X} 10^{12} / \mathrm{L}\right)$} \\
\hline & $3.04 \pm 0.49$ & $2.76 \pm 0.40$ & $4.88 \pm 0.30$ & 0.0001 \\
\hline & {$\left[\begin{array}{lll}2.07 & 3.76\end{array}\right]$} & {$\left[\begin{array}{lll}1.90 & 3.26\end{array}\right]$} & {$\left[\begin{array}{ll}4.38 & 5.34\end{array}\right]$} & \\
\hline \multicolumn{5}{|l|}{ Het (L/L) } \\
\hline & $0.25 \pm 0.04$ & $0.24 \pm 0.04$ & $0.43 \pm 0.04$ & 0.0001 \\
\hline & {$\left[\begin{array}{ll}0.17 & 0.32\end{array}\right]$} & {$\left[\begin{array}{ll}0.14 & 0.30\end{array}\right]$} & {$\left[\begin{array}{ll}0.40 & 0.50\end{array}\right]$} & \\
\hline \multicolumn{5}{|l|}{ MCV (fl) } \\
\hline & $79.99 \pm 7.29$ & $84.37 \pm 10.43$ & $88.10 \pm 3.26$ & 0.001 \\
\hline & {$\left[\begin{array}{lll}62.00 & 92.00\end{array}\right]$} & [54.80 94.00] & [83.00 92.00] & \\
\hline \multicolumn{5}{|l|}{ МCH (pg) } \\
\hline & $25.29 \pm 2.65$ & $27.20 \pm 3.98$ & $29.10 \pm 1.16$ & 0.0001 \\
\hline & {$\left[\begin{array}{lll}19.00 & 28.00\end{array}\right]$} & {$\left[\begin{array}{lll}18.60 & 30.00\end{array}\right]$} & [27.00 31.00] & \\
\hline \multicolumn{5}{|c|}{ МCHC (g/dl) } \\
\hline & $30.85 \pm 0.78$ & $31.89 \pm 1.09$ & $33.30 \pm 0.65$ & 0.0001 \\
\hline & [30.00 32.00] & [30.00 34.00] & [32.00 34.00] & \\
\hline \multicolumn{5}{|c|}{ Reticulocyte count (\%) } \\
\hline & $1.81 \pm 0.33$ & $1.90 \pm 0.40$ & $1.93 \pm 0.10$ & 0.328 \\
\hline & {$\left[\begin{array}{lll}0.84 & 2.24\end{array}\right]$} & {$\left[\begin{array}{lll}1.40 & 2.78\end{array}\right]$} & {$\left[\begin{array}{ll}1.82 & 2.10\end{array}\right]$} & \\
\hline
\end{tabular}

$[\mathrm{RBC}=$ Red blood cell, Hct $=$ Haematocrit, $\mathrm{MCV}=$ Mean corpuscular volume, $\mathrm{MCH}=$ Mean corpuscular haemoglobin, $\mathrm{MCHC}=$ Mean corpuscular haemoglobin concentration] 
Table III Iron profile of the study subjects

\begin{tabular}{lcccc} 
Parameter & $\begin{array}{c}\text { Group A } \\
(\mathrm{n}=30)\end{array}$ & $\begin{array}{c}\text { Group B } \\
(\mathrm{n}=40)\end{array}$ & $\begin{array}{c}\text { Group C } \\
(\mathrm{n}=30)\end{array}$ & $\mathrm{p}$ value \\
\hline Serum iron $(\mu \mathrm{g} / \mathrm{dl})$ & $45.67 \pm 16.63$ & $52.40 \pm 23.20$ & $90.20 \pm 22.59$ & $0.193^{*}$ \\
& & & & $0.0001^{* *}$ \\
& {$[16.0077 .00]$} & {$[21.0098 .0$} & {$[48.00132 .00]$} & $0.0001^{* * *}$ \\
TIBC $(\mu \mathrm{g} / \mathrm{dl})$ & $326.80 \pm 22.64$ & $221.80 \pm 44.23$ & $278.87 \pm 54.38$ & $0.0001^{*}$ \\
& & & & $0.0001^{* *}$ \\
& {$[292.00356 .00]$} & {$[144.0302 .00]$} & {$[168.00364 .00]$} & $0.0001^{* * *}$ \\
Serum ferritin $(\mu \mathrm{g} / \mathrm{L})$ & $101.23 \pm 119.42$ & $599.59 \pm 449.15$ & $83.73 \pm 45.09$ & $0.0001^{*}$ \\
& & & & $0.818^{* *}$ \\
& & & & $0.0001^{* * *}$ \\
TSAT $(\%)$ & $14.50515 .00]$ & {$[240.001936 .00]$} & {$[55.20214 .84]$} & $0.0001^{*}$ \\
& $16.47 \pm 6.47$ & $28.02 \pm 12.30$ & $27.50 \pm 6.22$ & $0.0001^{* *}$ \\
& & & & $0.816^{* * *}$ \\
\hline
\end{tabular}

* Group A vs Group B, ** Group A vs Group C, *** Group B vs Group C

Table IV Soluble transferrin receptor (sTfR) of the study subjects

\begin{tabular}{lcccc} 
Parameter & $\begin{array}{c}\text { Group A (IDA) } \\
(\mathrm{n}=30)\end{array}$ & $\begin{array}{c}\text { Group B (ACD) } \\
(\mathrm{n}=40)\end{array}$ & $\begin{array}{c}\text { Group C } \\
(\mathrm{n}=30)\end{array}$ & p value \\
\hline $\mathrm{sTfR}(\mu \mathrm{g} / \mathrm{ml})$ & $4.81 \pm 1.64$ & $2.89 \pm 1.40$ & $2.96 \pm 0.78$ & \\
& {$[3.3610 .30]$} & {$[0.935 .51]$} & {$[2.104 .57]$} & 0.0001 \\
\hline Group A vs Group B & & & & 0.0001 \\
Group A vs Group C & & & & 0.829 \\
Group B vs Group C & & & & \\
\hline
\end{tabular}

Table V Iron profile status in subgroups of ACD

\begin{tabular}{lccc} 
Iron status & $\begin{array}{c}\text { Group B } \\
\text { sTfR }<3(\mathrm{n}=24)\end{array}$ & $\begin{array}{c}\text { Group } B_{2} \\
\mathrm{sTfR} \geq 3(\mathrm{n}=16)\end{array}$ & $\mathrm{p}$ value \\
\hline Serum iron $(\mu \mathrm{g} / \mathrm{dl})$ & $62.00 \pm 23.25$ & $38.00 \pm 14.22$ & 0.0001 \\
TIBC $(\mu \mathrm{g} / \mathrm{dl})$ & $198.50 \pm 41.38$ & $256.75 \pm 16.99$ & 0.0001 \\
TSAT $(\%)$ & $31.17 \pm 11.62$ & $23.30 \pm 12.10$ & 0.157 \\
Serum ferritin $(\mu \mathrm{g} / \mathrm{ml})$ & $665.58 \pm 495.88$ & $500.61 \pm 360.65$ & 0.279 \\
\hline
\end{tabular}

A p value $<0.05$ was taken as level of significance.

Group $\mathrm{B}_{1}$ : Anemia of chronic disease (ACD) with $\mathrm{sTfR}<3 \mu \mathrm{g} / \mathrm{ml}$

Group $\mathrm{B}_{2}$ : Anemia of chronic disease (ACD) with $\mathrm{sTfR} \geq 3 \mu \mathrm{g} / \mathrm{ml}$ 
Table VI sTfR-ferritin indices in IDA and ACD group

\begin{tabular}{lccc} 
Parameters & $\begin{array}{c}\text { Group A } \\
(\mathrm{n}=30)\end{array}$ & $\begin{array}{c}\text { Group B } \\
(\mathrm{n}=40)\end{array}$ & P value \\
\hline sTfR:Log SF & $2.71 \pm 1.13$ & $1.08 \pm 0.54$ & 0.015 \\
Log sTfR:SF & $0.013 \pm 0.012$ & $0.001 \pm 0.0008$ & 0.0001 \\
\hline
\end{tabular}

Table VII sTfR-ferritin indices in subgroups of ACD

\begin{tabular}{lccc} 
sTfR & $\begin{array}{c}\text { Group } B_{1} \\
(\mathrm{n}=24)\end{array}$ & $\begin{array}{c}\text { Group } B_{2} \\
(\mathrm{n}=16)\end{array}$ & P value \\
\hline sTfR:Log SF & $0.69 \pm 0.19$ & $1.67 \pm 0.35$ & 0.001 \\
Log sTfR:SF & $0.26 \pm 0.13$ & $0.63 \pm 0.09$ & 0.001 \\
\hline
\end{tabular}

Group $\mathrm{B}_{1}$ : Anaemia of chronic disease (ACD) with sTfR $<3 \mu \mathrm{g} / \mathrm{ml}$

Group $\mathrm{B}_{2}$ : Anaemia of chronic disease (ACD) with sTfR $>3 \mu \mathrm{g} / \mathrm{ml}$

\section{Discussion}

sTfR levels are expected to be the highest in IDA as reported earlier by Dimitriou et $\mathrm{al}^{6}$, by Malope et $\mathrm{al}^{7}$ in their studies among pre-school children and also by Angeles et $\mathrm{al}^{8}$ and Hanif et $\mathrm{al}^{9}$ in different studies. In another study by Jain et al $^{10}$ all 21 IDA patients had significantly raised sTfR levels. In our study, mean sTfR level was higher in patients with IDA than in patients with ACD. In control group, sTfR value was low, as same as ACD group which reflects that it was not affected by inflammation or infection.

In a study by Jain et $\mathrm{al}^{10}$ ferritin level was significantly higher in ACD patients than IDA patients which was similar to current study. In this study mean ferritin level was $599.59 \pm 449.15 \mathrm{ig} / \mathrm{L}$ in ACD patients whereas $101.23 \pm 119.42 \mathrm{ig} / \mathrm{L}$ in IDA patients and also ferritin is lower in control group $(83.73 \pm 45.09 \mathrm{ig} / \mathrm{L})$ than IDA group. It has been shown that, ferritin values increased in IDA with CKD patients; may be due to chronic inflammatory process. In a study Gupta et $\mathrm{al}^{11}$, the serum ferritin was much higher in patients with CKD than in patients with IDA without CKD.

Serum iron was reduced in both IDA and ACD patients in the current study. Mean serum iron in patient with IDA and ACD was not significantly different, TIBC was significantly increased and TSAT was significantly reduced in IDA as compared to ACD. Similar findings were observed in a study by Jain et al ${ }^{10}$ conducted in
India. In another study by Gupta et $\mathrm{al}^{11}$, found that the mean value of serum iron in CKD patients was higher than IDA patients, whereas TIBC was lower in CKD patients with higher TSAT values.

In present study, mean sTfR level is higher in patients with IDA than in patients with ACD and control. sTfR level of ACD was much close to control group. Ferritin level was significantly high in ACD patients than IDA patients. Shilpa Jain et al ${ }^{10}$ showed that all cases in IDA group had sTfR/log ferritin index $>1.5$ and all pure ACD cases, control subjects and ACD with coexisting IDA had sTfR/log ferritin index $<1.5$. All cases in IDA group had $\log \mathrm{sTfR} /$ serum ferritin index $>2.55$ and all patients with ACD with or without associated iron deficiency had $\log \mathrm{sTfR} /$ serum ferritin ratio $<2.55$.

Gupta et $\mathrm{al}^{11}$ showed that a ratio of sTfR/Log ferritin $>1.4$ indicates co-existence of iron deficiency anemia with anemia of chronic disease, while ratio of up to 1.3 indicates anemia of chronic disease only.

It was seen in our study that $100 \%$ patients of IDA had $\mathrm{sTfR} / \log$ ferritin index of $>1.5$ while all pure ACD cases had sTfR $/ \log$ ferritin index $<1.5$. All patients with pure IDA had $\log \mathrm{sTfR} /$ ferritin ratio $>2.55$ and $100 \%$ cases of ACD with or without IDA had log sTfR/ ferritin ratio $<2.55$ as reported earlier by Malope BL et al. ${ }^{13}$ In our study, mean log sTfR/ferritin was significantly higher in patients with compared to patients with ACD. Thus, this index can help in differentiating pure IDA from ACD with or without co-existing iron deficiency. 
So, estimation of both Serum sTfR and sTfR-ferritin indices are able to differentiate pure IDA, ACD and $\mathrm{ACD}$ with co-existing iron deficiency and thus providing a non-invasive alternative to bone marrow iron staining.

Conflict of interest: Nothing to declare.

\section{References}

1. Talwar VK, Gupta HL, Shashinarayan. Clinico haematological profile in chronic renal failure. J Assoc physician India 2002;50:228-33

2. National kidney foundation. Kidney Disease outcomes quality initiative: clinical practice guidelines for anaemia of chronic kidney disease. IV NKF-K / DOQI, update 2000;37:S 182238.

3. Moreb J, Popovtzer MM, Friedlaender MM, Konjin AM, Hershko C. Evaluation of iron status in patients on chronic hemodialysis: Relative usefulness of bone marrow hemosiderin, serum ferritin, transferrin saturation, mean corpuscular volume and red cell protoporphyrin. Nephron 1983; 35: 196-200.

4. Saboor M, Moinuddin, Noreen A. Soluble transferrin receptor: a differentiating marker between iron deficiency anaemia and anaemia of chronic disorders, J Ayub Med Coll Abbottabad 2011;23(3): 75-80.

5. Chen Y, Hung S, Tarng D. Association Between Transferrin Receptor-Ferritin Index and Conventional Measures of Iron Responsiveness in Hemodialysis Patients. American Journal of Kidney Diseases 2006;47 (6):1036-44.
6. Dimitrou H, Stiakaki E, Markaki EA. Soluble transferrin receptor levels and soluble transferrin receptor/ log ferritin index in the evaluation of erythropoietic status in childhood infections and malignancy. Acta Paediatr 2000; 89: 1169-73.

7. Malope BL, Macphail AP, Albert M, Hiss DC. The ratio ofserum transferrin receptor and serum ferritin in diagnosis of iron status. Br J Haematol 2001; 115: 84-89.

8. Lopez M AV, Molonis FL, Carmona ML, Morales AC, Vico FJ, Munoz JL, et al. Serum transferrin receptor in children: usefulness for determining the nature of anemia in children. J Pediatr Hematol Oncol 2006; 28: 809-15.

9. Hanif E, Ayyub M, Anwar M, Ali W, Bashir M. Evaluation of serum transferrin receptor concentration in diagnosis and differentiating iron deficiency anemia from anemia of chronic disorders. J Pak Med Assoc 2005; 55: 13-16.

10. Jain S, Narayan S, Chandra J, Sharma S, Jain S, Malhan P. Evaluation of Serum Transferrin Receptor and sTfR Ferritin Indices in Diagnosing and Differentiating Iron Deficiency Anemia from Anemia of Chronic Disease Indian J Pediatr 2010; 77 (2): 179-83.

11. Gupta S, Uppal B, Pawar B. Is soluble transferrin receptor a good marker of iron deficiency anemia in chronic kidney disease patients? Indian Journal of Nephrology 2009; 19 (3):225-30.

12. DeGruchy's Clinical Heamatology in Medical Practice. Edited by Frank Firkin Colin chesterman, David penington \& Bryan Rush . 5th edition, Wiley India Pvt. Limited, India 2008; 35055 .

13. Malope BL, Macphail AP, Albert M, Hiss DC. The ratio ofserum transferrin receptor and serum ferritin in diagnosis of iron status. Br J Haematol 2001; 115: 84-89. 